\title{
Polynomial Regression Analysis for the Removal of Heavy Metal Mixtures in Coagulation/Flocculation of Electroplating Wastewater
}

\author{
Siti Wahidah Puasa ${ }^{1,2,}$, Kamariah Noor Ismail ${ }^{2}$, Muhammad Amarul Aliff Mahadi², Nur Ain Mohd \\ Zainuddin $^{1,2}$, and Mohd Nazmi Mohd Mukelas ${ }^{2}$ \\ ${ }^{1}$ Integrated Separation Technology Research Group (i-STRonG), Faculty of Chemical Engineering, Universiti Teknologi MARA, \\ 40450 Shah Alam, Selangor, Malaysia
}

${ }^{2}$ Faculty of Chemical Engineering, Universiti Teknologi MARA, 40450 Shah Alam, Selangor, Malaysia

\begin{abstract}
${ }^{*}$ Corresponding author:
tel: $+603-55436327$

email: sitiwahida@uitm.edu.my

Received: December 6, 2019

Accepted: May 11, 2020

DOI: $10.22146 /$ ijc. 52251

Abstract: Wastewater produced from the electroplating industry generally consists of heavy metal mixture and organic materials that need to be treated before it can be discharged to the environment. Thus, the present investigation was focused on the selective removal of heavy metal mixtures that consist of Copper (Cu), Cadmium (Cd), and Zinc ( $\mathrm{Zn})$. Several operating conditions, including the effect of $\mathrm{pH}$ and coagulant $\left(\mathrm{FeCl}_{3}\right)$ dosage, were varied to find the best performance of heavy metal removal. Results showed that the efficiency of heavy metals removal for 2 types of wastewaters were both approximately 99\%. The experimental data on the treatment of synthetic wastewater was plotted using polynomial regression (PR) via Excel software. The value of the adjusted $R^{2}$ obtained for the final concentration of $\mathrm{Cu}, \mathrm{Zn}$, and $\mathrm{Cd}$ after treatment were 0.6884, 0.9676, and 0.9283, respectively, which showed that the data were acceptably fitted for $\mathrm{Cu}$ and very well fitted for $\mathrm{Zn}$ and $\mathrm{Cd}$. The coagulation/flocculation process performed on actual wastewater showed that the lowest final concentration of $\mathrm{Cu}, \mathrm{Zn}$, and $\mathrm{Cd}$ after treatment were $0.487,1.232$, and $0 \mathrm{mg} / \mathrm{L}$ respectively, at $\mathrm{pH} 12$.
\end{abstract}

Keywords: hydroxide precipitation; metal removal; coagulation-flocculation; electroplating wastewater; polynomial regression

\section{- INTRODUCTION}

The fast emergence of urbanization and the development of industrial sectors, including metal coating manufacturing and electroplating industries, have led to environmental degradation in terms of industrial pollution. Wastewater produced from these industrial activities may consist of a variety of toxic substances, hence, becoming major environmental concerns if it is not properly treated [1-5]. The subsequent water from the acid pickling process, alkaline cleaning, plating, and rinsing activities are discharged in large quantities as wastewater, which contains heavy metals at high concentrations [6-7]. The metallic ions discharged from industries will remain suspended in water for an extended time [8]. The most common toxic heavy metals that are of concern in the treatment of industrial wastewater are zinc
$(\mathrm{Zn})$, copper $(\mathrm{Cu})$, mercury $(\mathrm{Hg})$, nickel $(\mathrm{Ni})$, cadmium (Cd), lead ( $\mathrm{Pb})$, and chromium (Cr) [9-14]. These heavy metals are toxic to the environment and may cause illness if consumed even at low concentrations. Each of these heavy metals is known to have significant effects on the health of individuals as well as impacts on the neurological system, and some of them are even carcinogenic [15]. The consequences are also severe to the aquatic ecosystem, even at low concentrations, because heavy metals are not degradable and will remain in the water for a long period of time [16-17]. Industries are facing challenges in treating their wastewater as the Department of Environment (DOE) is stringent on discharge concentration of heavy metals in wastewater via regulation, namely the Environmental Quality (Industrial Effluents) Regulation 2009 under the Environmental Quality Act (EQA) 1974 [18]. 
The nature of wastewater is a crucial consideration in suggesting the suitable treatment method for heavy metal removal from wastewater [13]. Researchers have explored several treatment technologies to remove heavy metals from industrial wastewater. These treatment approaches can be classified into three main categories: physical, chemical, and biological treatment, which includes adsorption [19-20], membrane filtration [21-22], ion exchange [23], coagulation-flocculation [24], up-flow anaerobic sludge blanket (UASB) [25], and electrochemical treatment technologies [26-28].

Hydroxide precipitation is a common method used for chemical precipitation [29]. Hydroxide precipitation is a process of removal of soluble metal ions from solution in the form of metal hydroxide precipitate. Metal hydroxide is formed when hydroxide ion $\left(\mathrm{OH}^{-}\right)$bonds to the metal ion $\left(\mathrm{Me}^{2+}\right)$ in the solution at a specific $\mathrm{pH}$. The reaction involved in hydroxide precipitation is [30]:

$\mathrm{Me}^{2+}+2 \mathrm{OH}^{-} \rightleftharpoons \mathrm{Me}(\mathrm{OH})_{2}$

The optimum $\mathrm{pH}$ for metal precipitation is selected at a minimum solubility concentration of the heavy metals [31-32]. Generally, metals such as $\mathrm{Ag}, \mathrm{Cd}, \mathrm{Cu}, \mathrm{Ni}$, $\mathrm{Pb}$, and $\mathrm{Zn}$ are soluble in acidic conditions, but their solubility decrease towards alkaline $\mathrm{pH}$. The optimum $\mathrm{pH}$ at minimum solubility is different for each of the heavy metals.

The coagulation/flocculation process was typically performed along with metal precipitation to enhance the destabilization of the suspended solid and enable the coprecipitation of heavy metals to create larger agglomerates or flocs. Thus, additional chemicals including ferric chloride $\left(\mathrm{FeCl}_{3}\right)$ or alum (PAC) as coagulants and surface charged polymers such as polyacrylamide (PAM) as flocculants are required to initiate the sedimentation of sludge containing heavy metals [33]. In coagulation/flocculation treatment, a coagulant is mainly used to destabilize colloids and form micro flocs, while flocculants function as a bridging agent for the micro flocs to form bigger flocs, dense enough to be able to settle in the sedimentation process $[13,34]$. This treatment process was found to be cost-efficient, easy to operate, and requires less energy compared to other treatment methods [35-36].
Recent studies mainly focus on single metal removal from synthetic wastewater via the coagulation/flocculation process. Results showed that an excellent removal rate was achieved via this treatment method [37]. However, actual wastewater typically consists of multi-metals. Since the optimum $\mathrm{pH}$ at minimum solubility is different for each of the heavy metals [38], it is a challenge to determine the optimum $\mathrm{pH}$ for the metal precipitation process. Several researchers have worked on the removal of heavy metal mixture from wastewater by metal precipitation [39]. Generally, the actual wastewater is substantially challenging to treat since the heavy metal content in the waste usually fluctuates as the industrial processes are being altered [40]. Therefore, some significant controls are necessary for the treatment process to achieve maximum removal of heavy metals.

Statistical analysis approaches such as polynomial regression (PR) can predict the effectiveness of a treatment process through mathematical equations [41]. These equations can generate the expected value of response in regards to the interrelated data of the treatment parameter [41-42]. This method has been implemented mostly in the chemical industries and other fields such as physics, engineering, biology [42]. Therefore, a statistical analysis study is important to verify the significant factor that influences the treatment of heavy metal mixture in actual wastewater. The optimization of the coagulation-flocculation process can be initiated by polynomial regression. By implementing statistical analysis, the time consumed on experimental work can be reduced, improving the cost of operation. Optimum conditions can be achieved after simulating the relationship between parameters such as initial $\mathrm{pH}$ of wastewater, initial heavy metal concentration, coagulant dosage, alkaline dosage, and flocculant dosage.

A study on synthetic wastewater is introduced to analyze the effect of parameters without the presence of any interference substance that can affect the statistical analysis. This study was performed to evaluate the performance of heavy metal mixture removal using hydroxide precipitation with co-precipitation via the coagulation/flocculation treatment process. The 
treatment was performed for synthetic wastewater and actual wastewater. The synthetic wastewater was an imitation of wastewater from electroplating industries, which consists of heavy metal mixtures of $\mathrm{Cu}, \mathrm{Zn}$, and $\mathrm{Cd}$. The parameter studies involved were the effect of metal concentration, operating $\mathrm{pH}$, and coagulant dosage on the performance of multi-metals removal. Polynomial regression (PR) analysis via Excel Software was used to analyze and verify the relationship between the percentage of metal removal response with parameters studied for the treatment of synthetic wastewater. The predicted results obtained from PR analysis were compared with the treatment of actual wastewater to evaluate the reliability of the mathematical expression in predicting the removal of heavy metals from wastewater.

\section{- EXPERIMENTAL SECTION}

\section{Materials}

The actual wastewater was collected from the raw wastewater of the electroplating industry. The synthetic wastewater was prepared from metal salts such as Cadmium(II) Nitrate Tetrahydrate $\left(\mathrm{CdN}_{2} \mathrm{O}_{6} \cdot 4 \mathrm{H}_{2} \mathrm{O}\right)$, Copper(II) Nitrate Trihydrate $\left(\mathrm{CuN}_{2} \mathrm{O}_{6} \cdot 3 \mathrm{H}_{2} \mathrm{O}\right)$, and Zinc(II) Nitrate Hexahydrate $\left(\mathrm{ZnN}_{2} \mathrm{O}_{6} \cdot 6 \mathrm{H}_{2} \mathrm{O}\right)$ purchased from Sigma Aldrich, Malaysia. The other reagents used were the industrial grade of Ferric Chloride $\left(\mathrm{FeCl}_{3}\right)$, Polyacrylamide (PAM), Sodium Hydroxide $(\mathrm{NaOH})$, and Sulfuric Acid $\left(\mathrm{H}_{2} \mathrm{SO}_{4}\right)$.

\section{Instrumentation}

The metal concentration was analyzed using Furnace Atomic Absorption Spectroscopy (Model HITACHI Z-2000). The percentage of the removal of heavy metals $(\% R)$ can be calculated by using the equation:

$\% \mathrm{R}=\frac{\left(\mathrm{C}_{0}-\mathrm{C}_{\mathrm{f}}\right)}{\mathrm{C}_{0}} \times 100 \%$

where $\mathrm{C}_{0}$ is the initial concentration of heavy metal and $\mathrm{C}_{\mathrm{f}}$ is the final concentration of heavy metal after treatment.

\section{Procedure}

\section{Sample collection and characterization}

The characterization of actual wastewater was collected at two different interval dates to determine the fluctuation of heavy metals in actual wastewater. Then, these samples were characterized for the heavy metal concentration, specifically focused on $\mathrm{Cu}, \mathrm{Zn}$, and $\mathrm{Cd}$. The $\mathrm{pH}$ condition of both samples of actual wastewater was also checked simultaneously.

\section{Preparation of synthetic wastewater}

Characterization results from actual wastewater were the basis for the preparation of synthetic wastewater. The synthetic wastewater containing $\mathrm{Cu}$, $\mathrm{Zn}$, and $\mathrm{Cd}$ were prepared by dissolving the respective heavy metal salts, namely cadmium(II) nitrate tetrahydrate $\left(\mathrm{CdN}_{2} \mathrm{O}_{6} \cdot 4 \mathrm{H}_{2} \mathrm{O}\right)$, copper(II) nitrate trihydrate $\left(\mathrm{CuN}_{2} \mathrm{O}_{6} \cdot 3 \mathrm{H}_{2} \mathrm{O}\right)$, and $\operatorname{zinc}(\mathrm{II})$ nitrate hexahydrate $\left(\mathrm{ZnN}_{2} \mathrm{O}_{6} \cdot 6 \mathrm{H}_{2} \mathrm{O}\right)$ in deionized water. The $\mathrm{pH}$ and metals concentration were prepared based on results obtained from the characterization of actual wastewater.

\section{Jar test}

The jar test experiments were carried out at room temperature. The initial $\mathrm{pH}$ was adjusted by using $\mathrm{H}_{2} \mathrm{SO}_{4}$. The jar test was set at $120 \mathrm{rpm}$ and $5 \mathrm{~min}$ for rapid mixing; $60 \mathrm{rpm}$ and $15 \mathrm{~min}$ for slow mixing. The hydroxide precipitation was conducted by adjusting operating $\mathrm{pH}$ via the addition of $\mathrm{NaOH}$ in the range of 8 to 12 with an interval of 0.5 . Next, the coagulation process was done by adding $\mathrm{FeCl}_{3}$ coagulant into the solution until $\mathrm{pH} 8$ was obtained. Both the hydroxide precipitation and coagulation process were performed under rapid mixing. For the flocculation process, PAM at a concentration of $40 \mathrm{mg} / \mathrm{L}$ was added into the solution under slow mixing to promote the formation of larger flocs. Residual metal concentration was determined after settling for 40 to $60 \mathrm{~min}$. Fig. 1 presents a flowchart of the treatment process.

The jar test experiments were conducted for synthetic and actual wastewater. For synthetic wastewater, two sets of samples were prepared according to the characterization results of actual wastewater obtained during sample collection and characterization.

\section{Polynomial regression via excel software}

Polynomial regression was performed to analyze and verify the relationship between the final concentration of heavy metals as response and the studied 


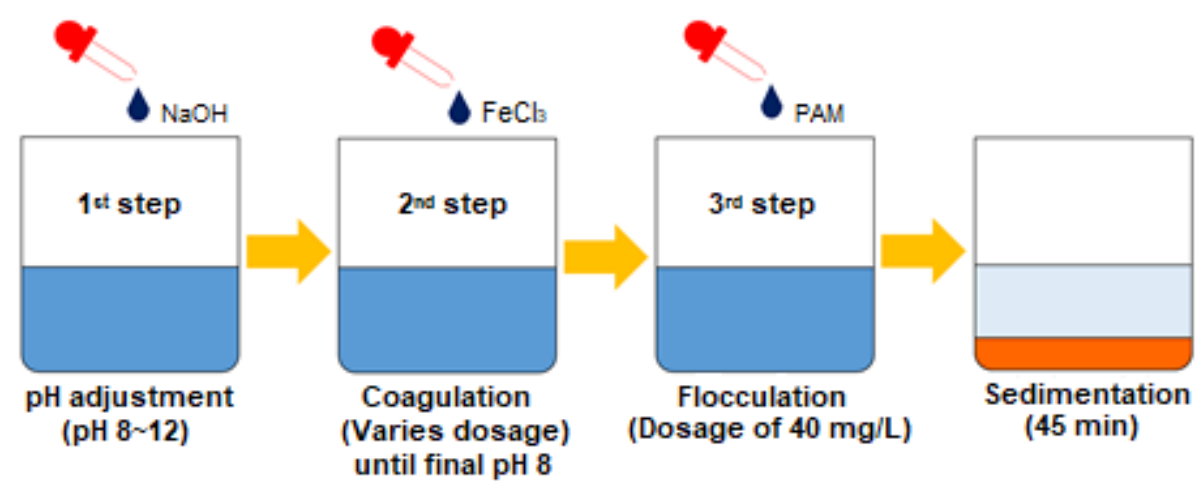

Fig 1. Flowchart of the treatment process

parameter as factor. The factors and responses are listed as follows:

$\mathrm{y}_{1}=$ Final concentration of $\mathrm{Cu}(\mathrm{mg} / \mathrm{L})$

$\mathrm{y}_{2}=$ Final concentration of $\mathrm{Zn}(\mathrm{mg} / \mathrm{L})$

$\mathrm{y}_{3}=$ Final concentration of $\mathrm{Cd}(\mathrm{mg} / \mathrm{L})$

$\mathrm{x}_{1}=$ Initial concentration of $\mathrm{Cu}(\mathrm{mg} / \mathrm{L})$

$\mathrm{x}_{2}=$ Initial concentration of $\mathrm{Zn}(\mathrm{mg} / \mathrm{L})$

$\mathrm{x}_{3}=$ Initial concentration of $\mathrm{Cd}(\mathrm{mg} / \mathrm{L})$

$\mathrm{x}_{4}=\mathrm{pH}$ for hydroxide precipitation

$\mathrm{x}_{5}=$ volume of $\mathrm{FeCl}_{3}(\mathrm{~mL})$

\section{- RESULTS AND DISCUSSION}

\section{Characterization of Actual Wastewater}

The samples obtained at two different interval dates were labeled as Sample 1 (S1) and Sample 2 (S2). Table 1 presents the characteristics of the actual wastewater for both samples. From this table, the actual wastewater was determined to be acidic and consisted of a high concentration of $\mathrm{Cu}$, followed by $\mathrm{Zn}$ and $\mathrm{Cd}$, which exceeded the allowable discharge limit as stipulated in IER2009.

\section{Effect of the $\mathrm{pH}$ of Hydroxide Precipitation on Heavy Metals Removal}

The removal of $\mathrm{Cu}, \mathrm{Zn}$, and $\mathrm{Cd}$ from two sets of synthetic wastewater (S1 and $\mathrm{S} 2$ ) via hydroxide precipitation followed by coagulation/flocculation process was conducted by adjusting the $\mathrm{pH}$ of the hydroxide precipitation between 8 to 12 through the addition of $\mathrm{NaOH}$ and reduced to neutral $\mathrm{pH}$ of 7.5 to 8 by addition of $\mathrm{FeCl}_{3}$ as co-precipitator and coagulant. The results are presented in Fig. 2. It is observed that $\mathrm{Cu}$ achieved the highest percentage removal, followed by $\mathrm{Zn}$ and Cd for both S1 and S2. This is due to the capability of metal mixtures to produce metal hydroxide precipitates at a certain $\mathrm{pH}$. The tendency of a metal to produce precipitate via hydroxide precipitation increase with the decrease of metal solubility concentration. The metal solubility concentration decreased in the sequence of $\mathrm{Cu}<\mathrm{Zn}<\mathrm{Cd}$ as the $\mathrm{pH}$ increased from 9 to 10.5 [38]. Therefore, the tendency of $\mathrm{Cu}$ to form hydroxide precipitation is higher than $\mathrm{Zn}$ and $\mathrm{Cd}$, hence resulting in the highest removal of $\mathrm{Cu}$ as compared to $\mathrm{Cd}$ and $\mathrm{Zn}$. The removal of metal mixtures for $\mathrm{S} 1$ at $\mathrm{pH} 9$ was $99.56 \%$ for $\mathrm{Cu}, 88.58 \%$ for $\mathrm{Zn}$, and $99.34 \%$ for $\mathrm{Cd}$. As for S2, the $\mathrm{Cu}$ removal was $99.34 \%$, followed by $\mathrm{Zn}(78.60 \%)$ and Cd (30.37\%).

Theoretically, the solubility concentration of metal hydroxide decreases as $\mathrm{pH}$ increases until it achieves its minimum solubility concentration. Further increase of $\mathrm{pH}$ will cause the metal hydroxide to resolubilize, hence increase the metal solubility concentration in aqueous

Table 1. Characteristics of actual wastewater

\begin{tabular}{cccccccc}
\hline \multicolumn{1}{c}{ Sample } & $\begin{array}{c}\text { Initial pH of } \\
\text { solution }\end{array}$ & $\begin{array}{c}\text { Initial COD } \\
\text { value }(\mathrm{mg} / \mathrm{L})\end{array}$ & $\begin{array}{c}\text { Initial TSS } \\
\text { Value }(\mathrm{mg} / \mathrm{L})\end{array}$ & \multicolumn{2}{c}{$\begin{array}{c}\text { Turbidity } \\
(\mathrm{mg} / \mathrm{L})\end{array}$} & \multicolumn{2}{c}{ Concentration of heavy metal (mg/L) } \\
\cline { 6 - 8 } & 1.5 & 318 & 9.5 & 4.8 & 80 & 10 & $\mathrm{Cu}$ \\
\hline Sample 1 (S1) & 1.5 & 276 & 8.2 & 4.1 & 40 & 20 & 2 \\
Sample 2 (S2) & $5.5-9.0$ & 200 & 100 & - & 1.0 & 2.0 & 0.02 \\
Standard B* & & &
\end{tabular}

^Allowable Discharge Limit by DOE [14] 


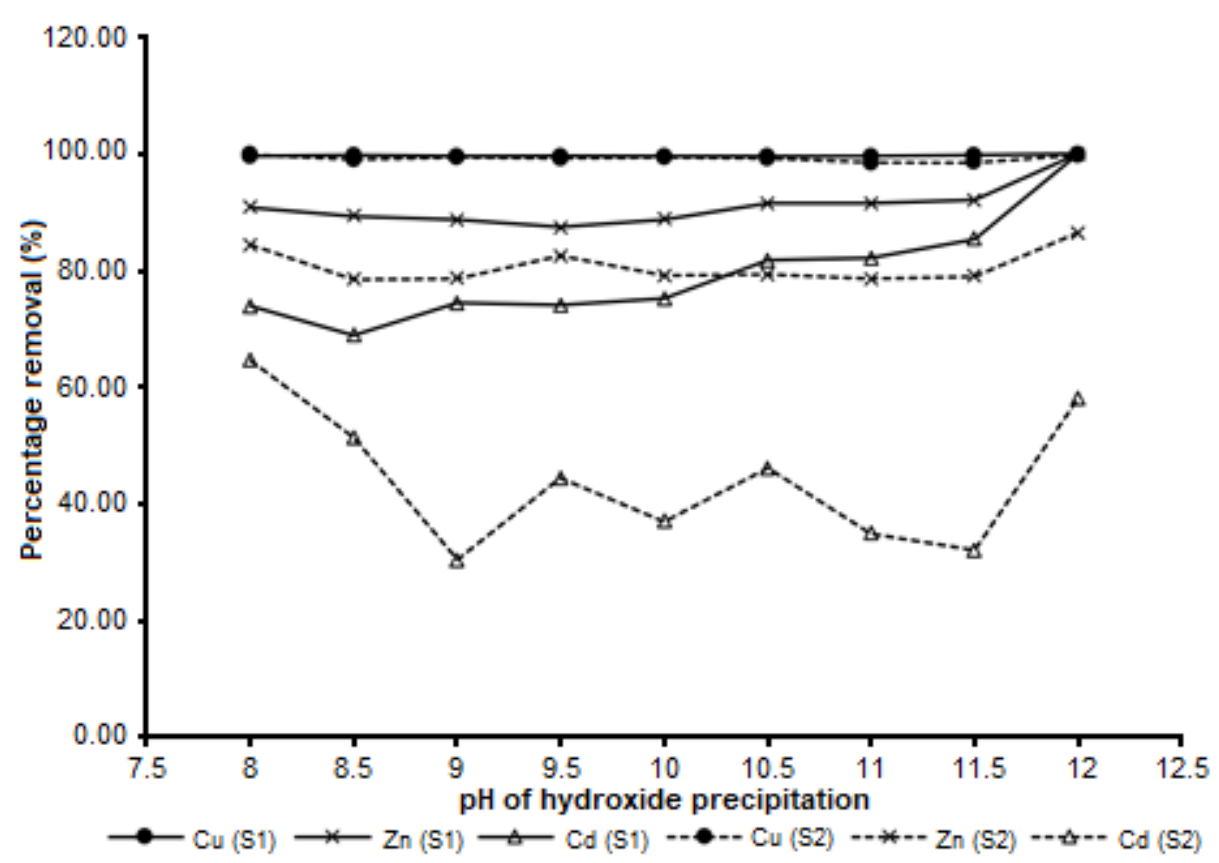

Fig 2. Percentage removal of $\mathrm{Cu}, \mathrm{Zn}$, and $\mathrm{Cd}$ for $\mathrm{S} 1$ and $\mathrm{S} 2$

solution. The metal solubility concentration decreased in the sequence of $\mathrm{Cd}<\mathrm{Cu}<\mathrm{Zn}$ as the $\mathrm{pH}$ increased from 10.8 to 12 [38]. It is theoretically predicted that $\mathrm{Cd}$ would achieve higher removal compared to $\mathrm{Cu}$ and $\mathrm{Zn}$ at $\mathrm{pH}$ between 11 to 12 . However, Fig. 2 shows that $\mathrm{Cu}$ obtained the highest removal at $\mathrm{pH} 8$ to 12 for both $\mathrm{S} 1$ and $\mathrm{S} 2$. This finding is resulted from the competitive hydroxide precipitation between $\mathrm{Zn}$ and $\mathrm{Cd}$ with the hydroxide ion due to the ionization energy factor. The ionization energy of different metals shows different reactiveness that attributable to the removal of an electron from its outer orbital [43]. The reactivity of elements in removing electrons to produce stable compounds increases with the decrease of the first ionization energy. The first ionization energy increase in the sequence of $\mathrm{Cu}>\mathrm{Cd}>\mathrm{Zn}$ at 745 , 868 , and $906 \mathrm{~kJ} / \mathrm{mol}$, respectively [43]. The hydrolysis of $\mathrm{Cu}, \mathrm{Cd}$, and $\mathrm{Zn}$ in aqueous solution creates competition with hydroxide ions $\left(\mathrm{OH}^{-}\right)$for the precipitation of metal ions at certain $\mathrm{pH}$. Thus, the efficiency of selective metal removal depends on the relative concentration of the anions $\left(\mathrm{OH}^{-}\right)$in the solution and is consequently $\mathrm{pH}$ dependent [44]. In this study, $\mathrm{Cu}$ has the lowest ionization energy compared to $\mathrm{Cd}$ and $\mathrm{Zn}$; hence tends to form hydroxide precipitate better than $\mathrm{Zn}$ and $\mathrm{Cd}$. Also, the concentration of $\mathrm{Cu}$ was 80 and 20 times higher than the concentration of Cd for S1 and S2, respectively. The presence of a high concentration of $\mathrm{Cu}$ will hinder the $\mathrm{Cd}$ ion from reacting with hydroxide ion, hence decreasing the potential for $\mathrm{Cd}$ ions to produce $\mathrm{Cd}(\mathrm{OH})_{2}$, even at its optimum $\mathrm{pH}$ of hydroxide precipitation. The highest removal of metal mixtures was obtained at $\mathrm{pH} 12$ for both S1 and S2. The removal of $\mathrm{Cu}, \mathrm{Zn}$, and $\mathrm{Cd}$ was $99.91 \%, 99.91 \%$, and $99.97 \%$, respectively for S1. For S2, the sequence of metal removal was $\mathrm{Cu}(99.71 \%)>\mathrm{Zn}(86.45 \%)>\mathrm{Cd}(58.11 \%)$. Johnson et al. [45] and Hargreaves et al. [16] observed similar findings where the removal of $\mathrm{Cu}$ was higher than $\mathrm{Zn}$ by using $\mathrm{FeCl}_{3}$ as the coagulant.

It was also observed that the removal of metal mixture for S1 was higher than S2. This phenomenon is due to the different initial metal concentrations used in the experiments. The concentration ratio for $\mathrm{Cu}: \mathrm{Zn}: \mathrm{Cd}$ was 80:10:1 and 20:10:1 for S1 and S2, respectively. The presence of a high concentration of $\mathrm{Cu}$ in $\mathrm{S} 1$ required a high amount of $\mathrm{NaOH}$ for $\mathrm{pH}$ adjustment. This resulted in a higher concentration of hydroxide ion in S1, hence increasing the tendency of more metal ions to form hydroxide precipitate compared to S2.

Fig. 3 presents the comparison of metal concentration after the coagulation/flocculation process 


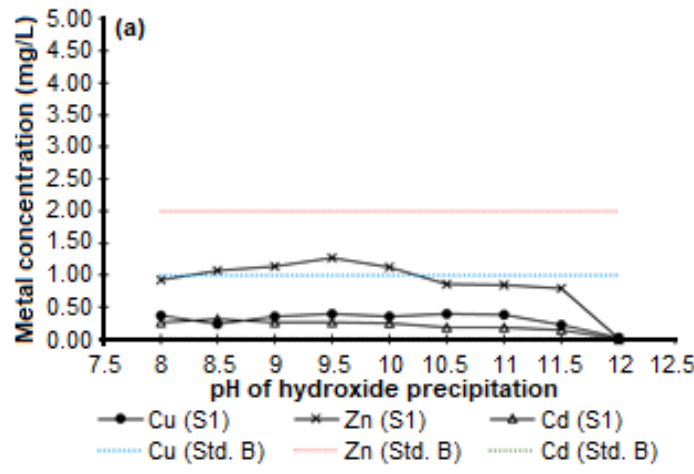

Fig 3. Comparison of metal concentration for (a) S1, and Standard B of IER 2009

with Standard B of IER 2009 under EQA 1974 for S1 and S2. It can be observed that the concentration of $\mathrm{Cu}$ and $\mathrm{Zn}$ complied with Standard B. Meanwhile, the Cd concentration only complied at $\mathrm{pH} 12$ for S1. From these findings, it can be concluded that the metal precipitation for multi-metals is influenced by metal solubility concentration and adequate dosing of $\mathrm{NaOH}$ to ensure complete hydroxide precipitation of multi-metals in aqueous solution. Therefore, a study on data verification using a mathematical model is useful in predicting the concentration of metals after coagulation/flocculation treatment at various initial metal concentrations.

\section{Polynomial Regression Analysis on Heavy Metals Removal}

A polynomial regression analysis via Excel Software was used to analyze and verify the relationship between the final concentration $\left(\mathrm{Cu}\left(\mathrm{y}_{1}\right), \mathrm{Zn}\left(\mathrm{y}_{2}\right)\right.$, and $\left.\mathrm{Cd}\left(\mathrm{y}_{3}\right)\right)$ and the parameters studied in this research. The selected parameters were the initial concentration $\left(\mathrm{Cu}\left(\mathrm{x}_{1}\right), \mathrm{Zn}\right.$ $\left(\mathrm{x}_{2}\right)$, and $\left.\mathrm{Cd}\left(\mathrm{x}_{3}\right)\right), \mathrm{pH}$ for hydroxide precipitation $\left(\mathrm{x}_{4}\right)$, and volume of $\mathrm{FeCl}_{3}\left(\mathrm{x}_{5}\right)$.

The best mathematical expression obtained for the prediction of the final concentration of metals $\mathrm{Cu}\left(\mathrm{y}_{1}\right), \mathrm{Zn}$ $\left(\mathrm{y}_{2}\right)$, and $\mathrm{Cd}\left(\mathrm{y}_{3}\right)$ can be expressed as:

$$
\begin{aligned}
& \mathrm{y}_{1}=\left(8.620 \times 10^{-2}\right) \mathrm{x}_{4}^{3}-2.427 \mathrm{x}_{4}^{2}+0.139 \mathrm{x}_{5}^{2}+ \\
& \left(7.549 \times 10^{-3}\right) \mathrm{x}_{2}^{2} \mathrm{x}_{5}-\left(4.356 \times 10^{-2}\right) \mathrm{x}_{4}^{2} \mathrm{x}_{5}+ \\
& \left(2.843 \times 10^{-2}\right) \mathrm{x}_{1} \mathrm{x}_{2} \mathrm{x}_{4}+\left(4.67 \times 10^{-3}\right) \mathrm{x}_{1} \mathrm{x}_{4} \mathrm{x}_{5}-70.647 \\
& \mathrm{y}_{2}=\left(2.863 \times 10^{-2}\right) \mathrm{x}_{5}^{3}-\left(2.85 \times 10^{-3}\right) \mathrm{x}_{4}^{2} \mathrm{x}_{1}- \\
& \left(7.83 \times 10^{-3}\right) \mathrm{x}_{4}^{2} \mathrm{x}_{2}-\left(4.885 \times 10^{-2}\right) \mathrm{x}_{5}^{2} \mathrm{x}_{2}+ \\
& \left(6.592 \times 10^{-3}\right) \mathrm{x}_{1} \mathrm{x}_{2} \mathrm{x}_{4}+\left(2.762 \times 10^{-3}\right) \mathrm{x}_{1} \mathrm{x}_{2} \mathrm{x}_{5}-21.681
\end{aligned}
$$

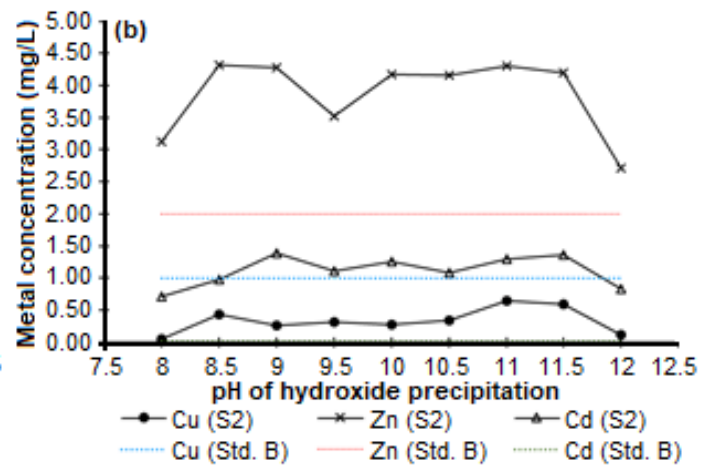

(b) S2 after the coagulation/flocculation process with

$$
\begin{aligned}
& \mathrm{y}_{3}=-\left(2.598 \times 10^{-4}\right) \mathrm{x}_{4}^{2} \mathrm{x}_{1}-\left(6.829 \times 10^{-3}\right) \mathrm{x}_{5}^{2} \mathrm{x}_{2}+ \\
& \left(3.615 \times 10^{-4}\right) \mathrm{x}_{1} \mathrm{x}_{2} \mathrm{x}_{4}+\left(3.834 \times 10^{-4}\right) \mathrm{x}_{1} \mathrm{x}_{4} \mathrm{x}_{5}-0.698
\end{aligned}
$$

The regression statistics and ANOVA for the expression above are presented in Table 2. From this table, it is depicted that for $\mathrm{Cu}, \mathrm{Zn}$, and $\mathrm{Cd}$, the significance $\mathrm{F}$, and the $\mathrm{P}$-value reported for intercept and all independent variables are less than 0.05; showing that the results are quite reliable and the variable is statistically significant [46-47]. The adjusted $\mathrm{R}^{2}$ obtained for $\mathrm{Zn}$ and $\mathrm{Cd}$ were 0.9676 and 0.9283 , respectively, indicating that the data were very well fitted. Meanwhile, for $\mathrm{Cu}$, the obtained adjusted $\mathrm{R}^{2}$ was 0.6884 , which shows that the data were acceptably fit, although it was slightly lower than the adjusted $\mathrm{R}^{2}$ of $\mathrm{Zn}$ and $\mathrm{Cd}$.

It is evident from Eq. (3), (4), and (5) that all independent variables or parameters depend on each other significantly except for the initial concentration of Cd $\left(x_{3}\right)$. The $x_{3}$ is also insignificant to the final concentration of $\mathrm{Cu}\left(\mathrm{y}_{1}\right), \mathrm{Zn}\left(\mathrm{y}_{2}\right)$, and $\mathrm{Cd}\left(\mathrm{y}_{3}\right)$. The concentration of $\mathrm{Cd}$ used in this study is considered very low; hence $\mathrm{Cd}$ does not influence the competitive hydroxide precipitation of multi-metals.

Fig. 4 shows the comparison between the experimental and predicted value of the final concentration of $\mathrm{Cu}\left(\mathrm{y}_{1}\right), \mathrm{Zn}\left(\mathrm{y}_{2}\right)$, and $\mathrm{Cd}\left(\mathrm{y}_{3}\right)$. It is clearly shown that the scatter plots of $\mathrm{Zn}$ and $\mathrm{Cd}$ are denser at around the 45-degree lines which indicates that the experimental data were close to the predicted value calculated from the mathematical expression. Meanwhile, several $\mathrm{Cu}$ scatter plots are distant from the 
Table 2. Regression statistics and ANOVA for the percentage of the final concentration of $\mathrm{Cu}, \mathrm{Zn}$, and $\mathrm{Cd}$

\begin{tabular}{|c|c|c|c|}
\hline \multicolumn{4}{|c|}{ Regression statistics and ANOVA } \\
\hline & $\mathrm{Cu}$ & $\mathrm{Zn}$ & $\mathrm{Cd}$ \\
\hline Multiple R & 0.9037 & 0.9895 & 0.9722 \\
\hline R Square & 0.8167 & 0.9790 & 0.9452 \\
\hline Adjusted R Square & 0.6884 & 0.9676 & 0.9283 \\
\hline Standard Error & 0.0896 & 0.2889 & 0.1337 \\
\hline Observations & 18 & 18 & 18 \\
\hline Significance F & 0.0048 & $1.383 \times 10^{-8}$ & $4.5271 \times 10^{-8}$ \\
\hline $\mathrm{P}$-value for intercept & 0.0275 & 0.0376 & 0.039 \\
\hline $\mathrm{P}$-value for $\mathrm{x}_{5}^{3}$ & - & 0.0190 & - \\
\hline $\mathrm{P}$-value for $\mathrm{x}_{4}^{3}$ & 0.0213 & - & - \\
\hline $\mathrm{P}$-value for $\mathrm{x}_{4}^{2}$ & 0.0234 & - & - \\
\hline $\mathrm{P}$-value for $\mathrm{x}_{5}^{2}$ & 0.0052 & - & - \\
\hline$P$-value for $x_{2}^{2} x_{5}$ & 0.0470 & - & - \\
\hline $\mathrm{P}$-value for $\mathrm{x}_{4}^{2} \mathrm{x}_{5}$ & 0.0233 & - & - \\
\hline $\mathrm{P}$-value for $\mathrm{x}_{4}^{2} \mathrm{x}_{1}$ & - & 0.0092 & $2.9590 \times 10^{-8}$ \\
\hline $\mathrm{P}$-value for $\mathrm{x}_{4}^{2} \mathrm{x}_{2}$ & - & 0.0459 & - \\
\hline$P$-value for $x_{5}^{2} x_{2}$ & - & 0.0005 & 0.0061 \\
\hline$P$-value for $x_{1} x_{2} x_{4}$ & 0.0254 & 0.02179 & $1.0774 \times 10^{-6}$ \\
\hline$P$-value for $x_{1} x_{2} x_{5}$ & - & 0.0076 & - \\
\hline $\mathrm{P}$-value for $\mathrm{x}_{1} \mathrm{x}_{4} \mathrm{x}_{5}$ & 0.0371 & - & 0.0117 \\
\hline
\end{tabular}
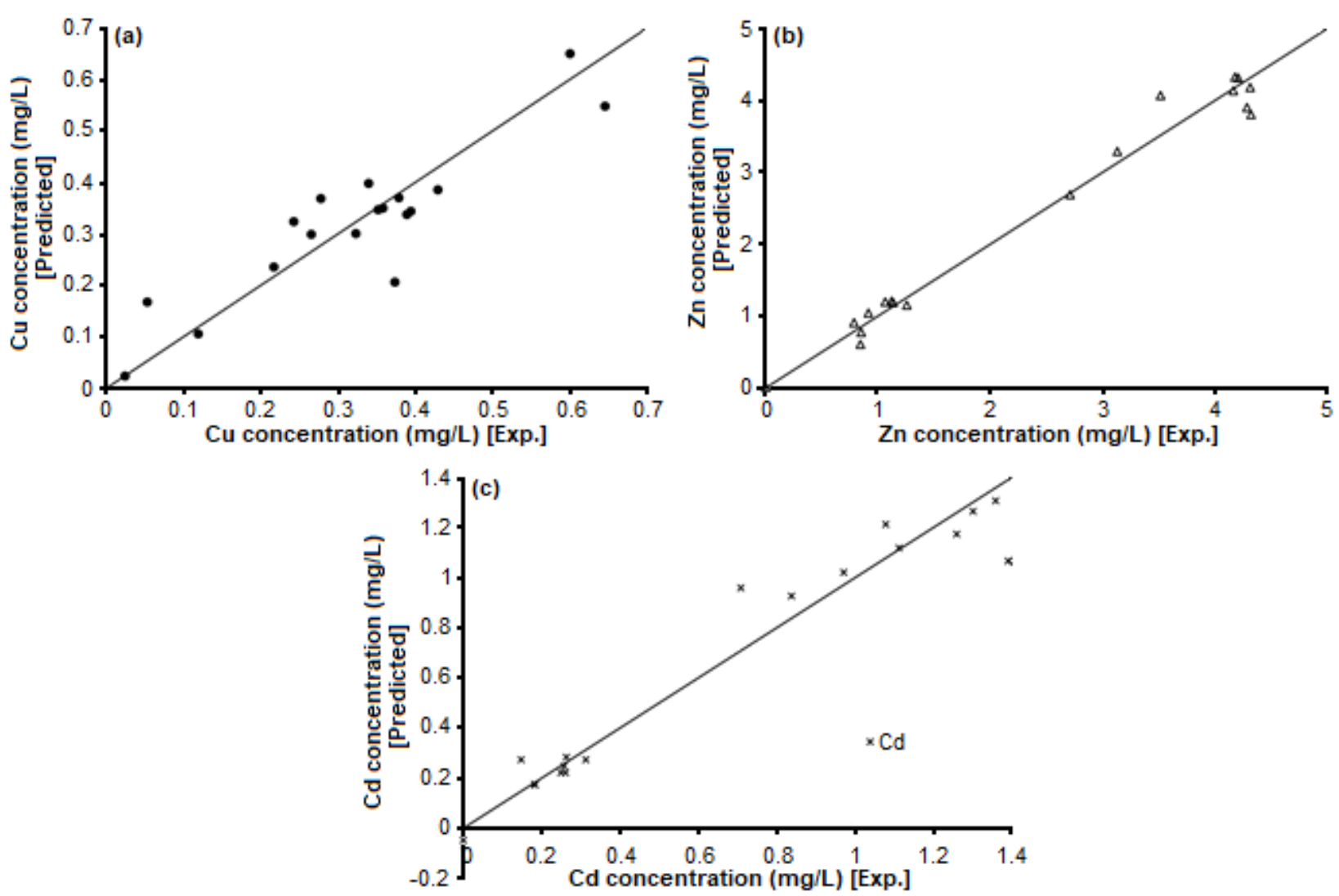

Fig 4. Comparison between the experimental and predicted value of the final concentration of (a) $\mathrm{Cu}$, (b) $\mathrm{Zn}$, and (c) $\mathrm{Cd}$ 
Table 3. Results of the heavy metal mixture before and after treatment for actual wastewater

\begin{tabular}{cccccccc}
\hline pH of hydroxide & Volume of & \multicolumn{3}{c}{ Initial metal concentration $(\mathrm{mg} / \mathrm{L})$} & \multicolumn{3}{c}{ Final metal concentration $(\mathrm{mg} / \mathrm{L})$} \\
\cline { 3 - 8 } precipitation & $\mathrm{FeCl}_{3}(\mathrm{~mL})$ & $\mathrm{Cu}$ & $\mathrm{Zn}$ & $\mathrm{Cd}$ & $\mathrm{Cu}$ & $\mathrm{Zn}$ & $\mathrm{Cd}$ \\
\hline 9.50 & 0.07 & 78.89 & 10.23 & 0.89 & 1.06 & 1.85 & 0.28 \\
10.00 & 0.07 & 78.89 & 10.23 & 0.89 & 1.17 & 1.36 & 0.18 \\
10.50 & 0.16 & 78.89 & 10.23 & 0.89 & 0.96 & 1.13 & 0.18 \\
11.00 & 0.67 & 78.89 & 10.23 & 0.89 & 0.87 & 1.15 & 0 \\
11.50 & 1.29 & 78.89 & 10.23 & 0.89 & 0.61 & 1.26 & 0 \\
12.00 & 3.43 & 78.89 & 10.23 & 0.89 & 0.49 & 1.23 & 0 \\
\hline
\end{tabular}

45-degree line, which is in agreement with the results of adjusted $\mathrm{R}^{2}$ obtained in Table 2 .

\section{Treatment of Actual Wastewater from the Electroplating Industry}

The treatment of actual wastewater from the electroplating industry was experimentally conducted via coagulation/flocculation method, while Eq. (3), (4), and (5) were used to predict the final concentration of $\mathrm{Cu}, \mathrm{Zn}$, and $\mathrm{Cd}$ for this treatment. Results for the final concentration of multi-metals obtained after treatment (Table 3) were compared with the predicted value and presented in Fig. 5. It is noticeable from this figure that the final concentration of multi-metals decreased with the increase of $\mathrm{pH}$ for hydroxide precipitation. The lowest final concentration of $\mathrm{Cu}, \mathrm{Zn}$, and $\mathrm{Cd}$ after treatment was $0.487,1.232$, and $0 \mathrm{mg} / \mathrm{L}$ respectively at hydroxide precipitation $\mathrm{pH}$ of 12, which complied with Standard B, of IER 2009. This finding is in good agreement with results obtained for coagulation/flocculation of synthetic wastewater. It is also evident from this finding that the presence of organic and other constituents in the actual wastewater does not influence the efficiency of the coagulation/flocculation process in multi metals removal. It is also observed from Fig. 5 that most of the final concentrations of $\mathrm{Zn}$ and $\mathrm{Cd}$ obtained from the predicted value were almost similar with error distribution between $2 \%$ to $19 \%$, except for $\mathrm{Cd}$ at $\mathrm{pH} 11$ to 12 , whereby Cd was completely removed at this condition. Most of the final concentrations of the multi-metals obtained from the experiments were found to be lower than the predicted value, especially for $\mathrm{Cu}$. Therefore, it can be concluded that the mathematical expression of Eq. (3), (4), and (5) are

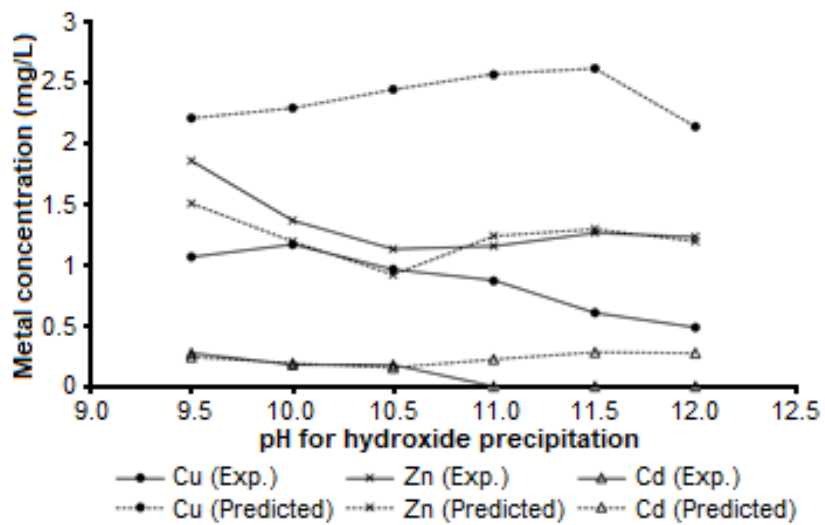

Fig 5. Final concentration of $\mathrm{Cu}, \mathrm{Zn}$, and $\mathrm{Cd}$ obtained from experiments and the predicted value for coagulation/flocculation treatment of actual wastewater

useful in predicting the final concentration of multimetals for the coagulation/flocculation process.

\section{- CONCLUSION}

The removal of synthetic multi-metals that consisted of $\mathrm{Cu}, \mathrm{Zn}$, and $\mathrm{Cd}$ was investigated in this study via coagulation/flocculation method using $\mathrm{NaOH}$ as the source of $\left(\mathrm{OH}^{-}\right)$ions and $\mathrm{FeCl}_{3}$ as the coagulant or co-precipitator. This method was found to be significantly capable of removing up to $100 \%$ of the multi-metals concentration in aqueous solution to meet the requirement as stipulated in the Environmental Quality (Industrial Effluent) Regulation (IER) 2009 under Environmental Quality Act (EQA) 1974. The highest removal achieved for $\mathrm{S} 1$ was $99.75 \%$ of $\mathrm{Cu}, 99.91$ of $\mathrm{Zn}$, and $99.98 \%$ of $\mathrm{Cd}$, while $99.71 \%$ of $\mathrm{Cu}, 86.45 \%$ of $\mathrm{Zn}$, and $58.11 \%$ of $\mathrm{Cd}$ removal were obtained for S2 at hydroxide precipitation $\mathrm{pH}$ of 12 . The final concentration of $\mathrm{Cu}, \mathrm{Zn}$, and $\mathrm{Cd}$ after coagulation/flocculation treatment 
were verified in this study by using polynomial regression $(\mathrm{PR})$ via Excel software. It was proven from the ANOVA analysis that the data were acceptably fitted for $\mathrm{Cu}$ and very well fitted for $\mathrm{Zn}$ and $\mathrm{Cd}$. The significance $\mathrm{F}$ and probability value obtained for all variables were less than 0.05 , which proved that the mathematical expression obtained from polynomial regression could be used to predict the final concentration of $\mathrm{Cu}, \mathrm{Zn}$, and $\mathrm{Cd}$ obtained after coagulation/flocculation treatment. The actual wastewater was successfully treated via the coagulation/flocculation method. The lowest final concentration of $\mathrm{Cu}, \mathrm{Zn}$, and $\mathrm{Cd}$ was $0.487,1.232$, and $0 \mathrm{mg} / \mathrm{L}$ respectively, at hydroxide precipitation $\mathrm{pH}$ of 12 , which complied with Standard B, of IER 2009. The mathematical expression obtained from $\mathrm{PR}$ was proven to be useful in predicting the final concentration of multimetals for the coagulation/flocculation process. Future works may focus on the optimization of hydroxide precipitation on the operating cost of the treatment process, including the disposal of sludge produced from treatment.

\section{- ACKNOWLEDGMENTS}

The authors gratefully acknowledge the support received from the Ministry of Higher Education Malaysia (MOHE) for the FRGS research funding 600-IRMI/FRGS 5/3 (103/2017), the Institute of Research Management \& Innovation (IRMI), and the Faculty of Chemical Engineering, Universiti Teknologi MARA, Shah Alam, Selangor, Malaysia that have made this important research viable and effective. The authors also wish to thank Mr. Shamsul Ahmad Aini for providing a technical consultant for this research study.

\section{- REFERENCES}

[1] Calzadilla, A., Rehdanz, K., and Tol, R.S.J., 2011, Water scarcity and the impact of improved irrigation management: A computable general equilibrium analysis, Agric. Econ., 42 (3), 305-323.

[2] Fu, F., and Wang, Q., 2011, Removal of heavy metal ions from wastewaters: A review, J. Environ. Manage., 92 (3), 407-418.

[3] Kim, C., Lee, C.R., Song, Y.E., Heo, J., Choi, S.M., Lim,
D.H., Cho, J., Park, C., Jang, M., and Kim, J.R., 2017, Hexavalent chromium as a cathodic electron acceptor in a bipolar membrane microbial fuel cell with the simultaneous treatment of electroplating wastewater, Chem. Eng. J., 328, 703-707.

[4] Chen, R., Liao, X., and Ge, Q., 2021, A novel multinuclear zinc complex Zn-Bet-Tf ${ }_{2} \mathrm{~N}$ for electroplating wastewater treatment using forward osmosis technique, Chem. Eng. J., 404, 126569.

[5] Yan, F.L., Wang, Y., Wang, W.H., Zhao, J.X., Feng, L.L., Li, J.J., and Zhao, J.C., 2020, Application of biochars obtained through the pyrolysis of Lemna minor in the treatment of Ni-electroplating wastewater, J. Water Process Eng., 37, 101464.

[6] Bankole, M.T., Abdulkareem, A.S., Mohammed, I.A., Ochigbo, S.S., Tijani, J.O., Abubakre, O.K., and Roos, W.R., 2019, Selected heavy metals removal from electroplating wastewater by purified and polyhydroxylbutyrate functionalized carbon nanotubes adsorbents, Sci. Rep., 9 (1), 4475.

[7] Martín-Lara, M.A., Blázquez, G., Trujillo, M.C., Pérez, A., and Calero, M., 2014, New treatment of real electroplating wastewater containing heavy metal ions by adsorption onto olive stone, J. Cleaner Prod., 81, 120-129.

[8] Martínez-Quiroz, M., López-Maldonado, E.A., Ochoa-Terán, A., Pina-Luis, G.E., and OropezaGuzman, M.T., 2018, Modification of chitosan with carbamoyl benzoic acids for testing its coagulantflocculant and binding capacities in removal of metallic ions typically contained in plating wastewater, Chem. Eng. J., 332, 749-756.

[9] Mehdipour, S., Vatanpour, V., and Kariminia, H.R., 2015, Influence of ion interaction on lead removal by a polyamide nanofiltration membrane, Desalination, 362, 84-92.

[10] Wang, G., Chang, Q., Han, X., and Zhang, M., 2013, Removal of $\mathrm{Cr}(\mathrm{VI})$ from aqueous solution by flocculant with the capacity of reduction and chelation, J. Hazard. Mater., 248-249, 115-121.

[11] Sudarsan, J.S., Deeptha, V.T., Maurya, D., Goel, M., Kumar, K.R., and Das, A., 2015, Study on treatment of electroplating wastewater using constructed 
wetland, Nat. Environ. Pollut. Technol., 14 (1), 95100.

[12] Zhao, S., Chen, Z., Shen, J., Kang, J., Qu, Y., Wang, B., Wang, X., and Yuan, L., 2017, Response surface methodology investigation into optimization of the removal condition and mechanism of $\mathrm{Cr}(\mathrm{VI})$ by $\mathrm{Na}_{2} \mathrm{SO}_{3} / \mathrm{CaO}, 2017$, J. Environ. Manage., 202 (Part 1), 38-45.

[13] Carolin, C.F., Kumar, P.S., Saravanan, A., Joshiba, G.J., and Naushad, M., 2017, Efficient techniques for the removal of toxic heavy metals from aquatic environment: A review, J. Environ. Chem. Eng., 5 (3), 2782-2799.

[14] Xiong, Z., Cao, J., Yang, D., Lai, B., and Yang, P., 2017, Coagulation-flocculation as pre-treatment for micro-scale $\mathrm{Fe} / \mathrm{Cu} / \mathrm{O}_{3}$ process $\left(\mathrm{CF}-\mathrm{mFe} / \mathrm{Cu} / \mathrm{O}_{3}\right)$ treatment of the coating wastewater from automobile manufacturing, Chemosphere, 166, 343-351.

[15] Rekha, T.M., Vinod, B., and Murthy, K.V.R., 2014, Removal of heavy metals from electroplating industry by electrocoagulation, JCHPS, 3, 111-118.

[16] Hargreaves, A.J., Vale, P., Whelan, J., Alibardi, L., Constantino, C., Dotro, G., Cartmell, E., and Campo, P., 2018, Impacts of coagulation-flocculation treatment on the size distribution and bioavailability of trace metals ( $\mathrm{Cu}, \mathrm{Pb}, \mathrm{Ni}, \mathrm{Zn})$ in municipal wastewater, Water Res., 128, 120-128.

[17] Siziba, N., Mwedzi, T., and Muisa, N., 2020, Assessment of nutrient enrichment and heavy metal pollution of headwater streams of Bulawayo, Zimbabwe, Phys. Chem. Earth., In Press, Corrected Proof.

[18] L.R. Board, 2017, Environmental Quality Act 1974 (Act 127), International Law Book Services, Malaysia.

[19] Jumina, Priastomo, Setiawan, H.R., Mutmainah, Kurniawan, Y.S., and Ohto, K., 2020, Simultaneous removal of lead(II), chromium(III), and copper(II) heavy metal ions through an adsorption process using C-phenylcalix[4]pyrogallolarene material, J. Environ. Chem. Eng., 8 (4), 103971.

[20] Sadeghi, M.H., Tofighy, M.A., and Mohammadi, T., 2020, One-dimensional graphene for efficient aqueous heavy metal adsorption: Rapid removal of arsenic and mercury ions by graphene oxide nanoribbons (GONRs), Chemosphere, 253, 126647.

[21] Aloulou, W., Aloulou, H., Khemakhem, M., Duplay, J., Daramola, M.O., and Amar, R.B., 2020, Synthesis and characterization of clay-based ultrafiltration membranes supported on natural zeolite for removal of heavy metals from wastewater, Environ. Technol. Innovation, 18, 100794.

[22] Hosseini, S.M., Alibakhshi, H., Jashni, E., Parvizian, F., Shen, J.N., Taheri, M., Ebrahimi, M., and Rafiei, N., 2020, A novel layer-by-layer heterogeneous cation exchange membrane for heavy metal ions removal from water, J. Hazard. Mater., 381, 120884.

[23] Tavakoli, O., Goodarzi, V., Saeb, M.R., Mahmoodi, N.M., and Borja, R., 2017, Competitive removal of heavy metal ions from squid oil under isothermal condition by CR11 chelate ion exchanger, J. Hazard. Mater., 334, 256-266.

[24] Sun, Y., Zhou, S., Pan, S.Y., Zhu, S., Yu, Y., and Zheng, H., 2020, Performance evaluation and optimization of flocculation process for removing heavy metal, Chem. Eng. J., 385, 123911.

[25] de la Varga, D.D.L., Díaz, M.A., Ruiz, I., and Soto, M., 2013, Heavy metal removal in an UASB-CW system treating municipal wastewater, Chemosphere, 93 (7), 1317-1323.

[26] Ya, V., Martin, N., Chou, Y.H., Chen, Y.M., Choo, K.H, Chen, S.S., and Li, C.W., 2018, Electrochemical treatment for simultaneous removal of heavy metals and organics from surface finishing wastewater using sacrificial iron anode, $J$. Taiwan Inst. Chem. Eng., 83, 107-144.

[27] Sun, J., Liu, L., and Yang, F., 2020, A WO $/$ PPy/ACF modified electrode in electrochemical system for simultaneous removal of heavy metal ion $\mathrm{Cu}^{2+}$ and organic acid, J. Hazard. Mater., 394, 122534.

[28] Tran, T.K., Chiu, K.F., Lin, C.Y., and Leu, H.J., 2017, Electrochemical treatment of wastewater: Selectivity of the heavy metals removal process, Int. Int. J. Hydrogen Energy, 42 (45), 27741-27748.

[29] US EPA, 1983, Methods for Chemical Analysis of Water and Wastes, EPA/600/4-79/020, U.S. 
Environmental Protection Agency, Washington, D.C.

[30] Abdullah, S.R.S., Rahman, R.A., Mohamad, A.B., Mustafa, M.M., and Khadum, A.A.H., 1999, Removal of mixed heavy metals by hydroxide precipitation, Jurnal Kejuruteraan, 11 (2), 85-101.

[31] Pascual, D., and McPhee, M., 2015, Fulfilment of EPA Discharge Requirements for ARD Using CoPrecipitation Iron Process at Neutral $\mathrm{pH}, 10^{\text {th }}$ International Conference on Acid Rock Drainage \& IMWA Annual Conference, 21-24 April 2015, Santiago, Chile.

[32] APHA, 2014, Standard Methods for the Examination of Water and Wastewater, American Public Health Association, Washington, D.C.

[33] Hashim, M.A., Mukhopadhyay, S., Sahu, J.N., and Sengupta, B., 2011, Remediation technologies for heavy metal contaminated groundwater, J. Environ. Manage., 92 (10), 2355-2388.

[34] Daud, N.M., Abdullah, S.R.S., and Hasan, H.A., 2018, Response surface methodological analysis for the optimization of acid-catalyzed transesterification biodiesel wastewater pre-treatment using coagulation-flocculation process, Process Saf. Environ. Prot., 113, 184-192.

[35] AlMubaddal, F., AlRumaihi, K., and Ajbar, A., 2009, Performance optimization of coagulation/flocculation in the treatment of wastewater from a polyvinyl chloride plant, J. Hazard. Mater., 161 (1), 431-438.

[36] Bratskaya, S.Y., Pestov, A.V., Yatluk, Y.G., and Avramenko, V.A., 2009, Heavy metals removal by flocculation/precipitation using N-(2carboxyethyl)chitosans, Colloids Surf., A, 339 (1-3), 140-144.

[37] Ghorpade, A., and Ahammed, M.M., 2018, Water treatment sludge for removal of heavy metals from electroplating wastewater, Environ. Eng. Res., 23 (1), 92-98.

[38] US EPA, 1984, Development Document for Effluent Limitations Guidelines and Standards for the Copper
Forming Point Source Category, U.S. Environmental Protection Agency, Washington, D.C.

[39] Ngatenah, S.N.I., Kutty, S.R.M., and Isa, M.H., 2010, Optimization of heavy metal removal from aqueous solution using groundwater treatment plant sludge (GWTPS), International Conference on Environment 2010 (ICENV 2010), 15 December 2010, Penang, Malaysia.

[40] Kobielska, P.A., Howarth, A.J., Farha, O.K., and Nayak, S., 2018, Metal-organic frameworks for heavy metal removal from water, Coord. Chem. Rev., 358, 92-107.

[41] Ebrahimi, M., Gerber, E.L., and Rockaway, T.D., 2017, Temporal performance assessment of wastewater treatment plants by using multivariate statistical analysis, J. Environ. Manage., 193, 234246.

[42] Santos, B., Galinha, C.F., Crespo, J.G., Santos, M.A., and Velizarov, S., 2013, Prediction of polar oil and grease contamination levels in refinery wastewater through multivariate statistical modeling, Sep. Purif. Technol., 119, 51-57.

[43] Ebbing, D.D., and Gammon, S.D., 2016, General Chemistry, $10^{\text {th }}$ Ed., Cengage Learning, Boston, US.

[44] Liu, D.H.F., and Liptak, B.G., 1997, Environmental Engineers' Handbook, $2^{\text {nd }}$ Ed., CRC Press, Boca Raton, Florida, US.

[45] Johnson, P.D., Girinathannair, P., Ohlinger, K.N., Ritchie, S., Teuber, L., and Kirby, J., 2008, Enhanced removal of heavy metals in primary treatment using coagulation and flocculation, Water Environ. Res., 80 (5), 472-479.

[46] Brown, A.M., 2001, A step-by-step guide to nonlinear regression analysis of experimental data using a Microsoft Excel spreadsheet, Comput. Methods Programs Biomed., 65 (3), 191-200.

[47] Hu, G., Li, J., and Hou, H., 2015, A combination of solvent extraction and freeze thaw for oil recovery from petroleum refinery wastewater treatment pond sludge, J. Hazard. Mater., 283, 832-840. 